\title{
META-ANALYSIS THE EFFECT OF CHRONIC DISEASE ON CATASTROPHIC HEALTH EXPENDITURE
}

\author{
Yeny Ristaning Belawati'), Didik Gunawan Tamtomo²), Bhisma Murti' ${ }^{1)}$ \\ ${ }^{1)}$ Masters Program in Public Health, Universitas Sebelas Maret \\ 2)Faculty of Medicine, Universitas Sebelas Maret
}

\begin{abstract}
Background: The growing prevalence of chronic diseases contributed to high financial risks of health care. High total out-of-pocket health expenditure relative to income can result in catastrophic health expenditure. This meta-analysis was performed to assess the effect of chronic disease on catastrophic health expenditure.

Subjects and Method: Meta-analysis and systematic review was conducted by collecting articles from Google Scholar, PubMed, Springer Link databases, which published from year 2000 to 2020. Keywords to collect the articles including," chronic disease" OR "chronic illness" AND "catastrophic health expenditure" OR "financial burden" AND "cross sectional" AND "adjusted odds ratio". The inclusion criteria were full text, in English language, using cross-sectional study design, and reporting adjusted odds ratio. Catastrophic health expenditure criteria if capacity to pay was $\geq 40 \%$ (excluding primary needs). The study population was households. The intervention was chronic disease with comparison non chronic disease. The study outcome was catastrophic health expenditure. The articles were selected by PRISMA flow chart. The quantitative data were analyzed using Revman 5.3.

Results: 9 studies from Tanzania, Korea, China, Ghana, and India were selected for this study. This study showed that chronic disease increased catastrophic health expenditure $(\mathrm{aOR}=1.94 ; 95 \% \mathrm{CI}=1.45$ to $2.54 ; \mathrm{p}<0.001)$.
\end{abstract}

Conclusion: Chronic disease increases catastrophic health expenditure.

Keywords: chronic disease, catastrophic health expenditure

Correspondence:

Yeny Ristaning Belawati. Masters Program in Public Health, Universitas Sebelas Maret. Jl. Ir. Sutami 36A, Surakarta 57216, Central Java. Email: belawatiyeni@gmail.com. Mobile: 082243302740.

The $7^{\text {th }}$ International Conference on Public Health Solo, Indonesia, November 18-19, 2020 | 364 https://doi.org/10.26911/the7thicph.04.49 